\title{
SIMBOL AGAMA HINDU SEBAGAI PRODUK TATO DI KUTA
}

\author{
Ni Putu Suwartini ${ }^{1}$, I Made Sendra ${ }^{2}$, Yohanes Kristianto ${ }^{3}$ \\ ${ }^{1}$ Email : ptsuartini12@gmail.com \\ Program Studi S1 Industri Perjalanan Wisata, Fakultas Pariwisata, Universitas Udayana \\ 2Email : sendramade65@gmail.com \\ Program Studi S1 Industri Perjalanan Wisata, Fakultas Pariwisata, Universitas Udayana \\ ${ }^{3}$ Email : yohanes_ipw@unud.ac.id \\ Program Studi S1 Industri Perjalanan Wisata, Fakultas Pariwisata, Universitas Udayana
}

\begin{abstract}
Tourists are interested in creative industry products with Balinese style and culture. The symbol of religion is a business opportunity developed by Bali's creative industries. Commodification of the sacred symbol of Hinduism in the form of tattoos occurs because of the tourist demand for tattoos in the form of Hindu religious symbols. This research was conducted in Kuta. Determination of informants using basic informant techniques and key informants. Data was collected through interviews conducted with Jero Bendesa Adat Kuta as the base informant and tattoo artist as the key informant. The data analysis technique used is descriptive qualitative. The results of this study indicate that the commodity of Hindu holy symbols in the form of tattoos as creative industrial products in Kuta occurs because of the demand for tourists and because there are no rules regarding the use of Hindu symbols in the form of tattoos. Commodification occurs in the value of the sacred symbols of Hindu religion which are sacred to commercial value. Commodification occurs in the function of the sacred symbol of Hinduism which functions as a sacred object into an object that functions as an art. This commodification does not change the original form of the sacred symbol of Hinduism, only a few variations are added such as flowers, lines, circles and so on.
\end{abstract}

Abstrak: Wisatawan tertarik akan produk industri kreatif dengan gaya dan bentuk budaya Bali. Simbol agama menjadi peluang bisnis yang dikembangkan oleh industri kreatif Bali. Komodifikasi simbol suci agama Hindu dalam bentuk tato terjadi karena adanya permintaan wisatawan akan tato dengan bentuk simbol agama Hindu. Penelitian ini dilakukan di Kuta. Penentuan informan menggunakan teknik informan pangkal dan informan kunci. Data dikumpulkan melalui wawancara yang dilakukan kepada Jero Bendesa Adat Kuta selaku informan pangkal dan seniman tato selaku informan kunci. Teknik analisis data yang digunakan adalah deskriptif kualitatif. Hasil dari penelitian ini menunjukan bahwa komodifkais simbol suci agama Hindu dalam bentuk tato sebagai produk indutri kreatif di Kuta terjadi karena adanya permintaan wisatawan dan karena belum adanya aturan mengenai penggunaan simbol agama Hindu dalam bentuk tato. Komodifikasi terjadi pada nilai dari simbol suci agama Hindu yang bernilai sakral menjadi bernilai komersil. Komodifikasi terjadi pada fungsi dari simbol suci agama Hindu yang berfungsi sebagai benda sakral menjadi benda yang berfungsi seni. Komodifikasi ini tidak merubah bentuk asli dari simbol suci agama Hindu, hanya ditambah sedikit variasi seperti bunga, garis, lingkaran dan lain sebagainya.

Keywords: tatto, creative industries, holy symbols of hinduism. 


\section{PENDAHULUAN}

Pariwisata merupakan sektor yang dianggap mampu meningkatkan perekonomian suatu daerah. Kunjungan wisatawan ke suatu daerah berpengaruh terhadap perekonomian dan kesejahteraan penduduk disekitar daerah tersebut. Besar atau kecilnya pengaruh berada di setiap daerah maupun di setiap negara (Sammeng dalam Rahma dan Hadayani, 2013).

Bali merupakan salah satu pulau di Indonesia yang dianggap sebagai magnet yang mampu menarik wisatawan untuk datang berkunjung. Pariwisata Bali tidak hanya menawarkan keindahan alam saja, tetapi keberagaman dan keunikan budaya juga mampu menjadi daya tarik bagi wisatawan. Kebudayaan Bali memiliki hubungan yang erat dengan seni.

Kesenian dalam pariwisata Bali pada umumnya mengandalkan seni pertunjukan sebagai ikon andalan untuk menarik wisatawan datang berkunjung. Hal tersebut bisa dilihat dari banyaknya tempat-tempat wisata di Bali yang menyuguhkan seni pertunjukan sebagai atraksi wisata. Contohnya di daerah Batubulan yang menyuguhkan pertunjukan tari barong dan kris, Tanah Lot yang menyuguhkan tarian kecak, Uluwatu yang memadukan tari kecak dengan keindahan matahari terbenam (sunset) dan masih banyak lagi.

Selain seni pertunjukan, seni lukis juga menjadi salah satu daya tarik bagi wisatawan. Banyak galeri-galeri lukisan yang tersebar di pulau Bali, seperti Gianyar, Klungkung dan Badung. Seni lukis pada umumnya menggunkan kanvas, kertas dan papan sebagi media untuk melukis. Namun dengan perkembangan zaman, banyak seniman lukis mulai melukis dengan menggunakan berbagai media baru seperti telur, logam, kayu, bahkan tubuh manusia.

Selain seni pertunjukan dan seni lukis ada satu seni lagi yang memiliki tempat dan pasarnya tersendiri yaitu seni tato. Seni tato merupakan salah satu jenis seni yang memiliki penggemar fanatik. Di Negara yang berbeda seni tato juga menjadi salah satu budaya yang memiliki ciri khasnya masing-masing. Seperti seni tato di Negara Thailand, Selandia baru, Afrika, Jepang dan masih banyak lagi. Di Indonesia sendiri seni tato juga merupakan salah satu tradisi yang diwariskan secara turun temurun. Suku di Indonesia yang menjadikan seni tato sebagai tradisi yaitu Suku Dayak di Kalimantan, Suku Mentawai di Sumatera Barat,
Suku Moi di Papua dan masih banyak lagi. (Setiawan, 2016).

Di Bali seni tato berkembang begitu pesat, hal tersebut bisa dilihat dari banyaknya studio-studio tato yang tersebar dihampir setiap daerah pulau ini. Seperti contoh di daerah Kuta, studio tato bisa ditemui di setiap penjuru daerah ini. Peminat seni tato tidak hanya dari kalangan lokal saja melaikan wisatawan mancangara juga datang ke Bali hanya untuk menato tubuhnya (berdasarkan hasil wawancara dengan Bapak Putra selaku seniman tato di Kuta, 14 September 2019).

Seni tato dibagi menjadi dua yaitu seni tato temporary dan seni tato permanen. Seni tato temporary yaitu seni tato yang dapat hilang dalam waktu 1-2 minggu sedangkan tato permanen hanya dapat hilang dengan cara di laser atau pencahayaan. Bentuk dan jenis tato begitu beragam seperti: tradisional, mandala, blackworks, watercolour dan lain sebagainya. Saat ini banyak wisatawan yang mulai tertarik dengan tato berbentuk simbol-simbol suci agama seperti: Salib, Om Kara, lambang Allah, Ganesha dan lain sebagainya.

Simbol-simbol suci agama merupakan benda yang memiliki nilai sakral, yang digunakan pada saat upacara keagamaan. Simbol-simbol suci agama Hindu ini ternyata memiliki daya tarik tersendiri bagi wisatawan. Sehingga banyak wisatawan yang menginginkan oleh-oleh dengan bentuk dan simbol-simbol suci agama Hindu. Hal tersebut menjadikan perindustrian pariwisata Bali mulai berlomba-lomba menciptakan produk industri kreatif dengan bentuk dan simbol-simbol suci Agama Hindu.

Produk industri kreatif dengan bentuk simbol-simbol suci agama Hindu seperti baju dengan gambar Barong, Dewa Ganesha, Pura Ulun Danu. Selain baju ada gelang tridatu yang kini di perjual belikan kepada wisatawan, kalung dengan lambang Om Kara, Ganesha, cakra dan masih banyak lagi. Selain sebagai oleh-oleh atau souvenir, simbol suci agama Hindu banyak digunakan sebagai tato.

Penggunaan simbol-simbol suci Agama Hindu sebagai souvenir dan tato ini disebut dengan komodifikasi. Komodifikasi merupakan proses transformasi barang atau jasa untuk meraih sebuah keuntungan. Komodifikasi terhadap simbol-simbol suci agama Hindu dilakukan demi memenuhi kebutuhan pasar atau wisatawan. 
Simbol suci agama Hindu merupakan benda sakral yang memiliki nilai suci yang difungsikan sebagai sarana untuk memperkuat keyakinan dan ketaqwaan umat beragama kepada Tuhan Yang Maha Esa. Simbol suci ini memiliki makna yang suci bagi umat Hindu. Simbol suci agama Hindu merupakan benda sakral yang bernilai suci yang di pergunakan pada saat upacara agama. Simbol agama dianggap suci dan memiliki fungsi apabila telah disakralisasi dengan rangkaian upacara agama. Sedangkan simbol agama yang belum disakralisasi merupakan benda mati biasa yang bermakna sebagai benda seni dan difungsikan sebagai produk industri kreatif yang di peruntunkan untuk wisatawan. Contohnya : simbol agama Hindu dalam bentuk patung yang fungsinya sebagai souvernir, lukisan simbol agama yang dijadikan sebagai seni lukis dan diperuntunkan untuk pariwisata, tato dengan bentuk simbol suci agama Hindu yang dilukis pada tubuh manusia sebagai salah satu produk industri kreatif dan masih banyak lagi. (Titib, 2001).

Komodifikasi simbol suci tidaklah salah. Simbol suci yang dijadikan sebagai souvernir, tato, lukisan, baju, kalung dan lain sebagainya tidak salah karena simbol-simbol tersebut belum disakralkan atau disucikan dengan rangkaian upacara tertentu, sehingga simbol tersebut belum memiliki makna dan fungsi yang suci. Dan belum ada aturan tentang penggunaan simbol suci agama Hindu sebagai produk industri kreatif. (Wawancara bersama Jero Bendesa Adat Kuta, 14 September 2019).

\section{METODE}

Penelitian ini dilakukan di kawasan pariwisata Kuta Kabupaten Badung. Kemudian peneliti melakukan wawancara yang diajukan kepada seniman tato di Kuta, Jero Bendesa adat Kuta, Pemangku di Kuta, masyarakat lokal Kuta, dan wisatawan yang menggunakan jasa tato di lokasi penelitian. Untuk menunjang pembahasan dalam penulisan ini, peneliti mewawancarai orang-orang yang memahami tentang simbol-simbol suci agama Hindu dan mengerti tentang tato yaitu informan pangkal dan informan kunci. Informan pangkal yaitu orang yang mengerti tentang simbol-simbol suci agama Hindu dan tentang penggunaan simbol-simbol suci agama Hindu dalam bentuk tato adalah Jero Bendesa adat Kuta yang tinggal di Kuta yang memahami tentang simbol-simbol suci agama Hindu dan penggunaan simbol-simbol suci agama Hindu dalam bentuk tato. Sedangkan informan kunci dalam penelitian ini adalah seniman tato yang memahami tentang tato, bentuk tato dan penggunaan simbol -simbol suci agama Hindu dalam bentuk tato.

Berdasarkan penjelasan sebelumnya, Penelitian ini mewawancarai informan di kawasan pariwisata Kuta menggunakan teori Tourist Art menurut Picard, 2006. Tourist Art merupakan kesenian sakral yang dikomodifikasi menjadi kesenian yang bersifat komersil dan diperuntunkan untuk memenuhi kebutuhan pariwisata. Variabel pertama yang digunakan dalam penelitian ini serta untuk membatasi ruang lingkup permasalahan penelitian adalah Bentuk, Fungsi dan Makna Simbol-Simbol Suci Agama Hindu. Yang dimaksud dengan Bentuk, Fungsi dan Makna Simbol-Simbol Suci Agama Hindu dalam penelitian ini meliputi (1) Bentuk SimbolSimbol Suci Agama Hindu (2) Fungsi SimbolSimbol Suci Agama Hindu, dan (3) Makna Simbol-Simbol Agama Hindu. Variabel kedua yang digunakan dalam penitian ini adalah Bentuk, Fungsi dan Makna Simbol-Simbol Suci Agama Hindu Dalam Tato. Yang dimaksud dengan Bentuk, Fungsi dan Makna SimbolSimbol Suci Agama Hindu Dalam Tato dalam penelitian ini meliputi (1) Komodifikasi Bentuk Simbol-Simbol Suci Agama Hindu, (2) Komodifikasi Fungsi Simbol-Simbol Suci Agama Hindu, dan (3) Komodifikasi Makna Simbol-Simbol Suci Agama Hindu.

Teknik pengumpulan data dilakukan dengan observasi, dokumentasi, studi pustaka dan wawancara. Teknik penentuan informan dibagi menjadi 2 yaitu informan pangkal dan informan kunci, pengumpulan data dilakukan dengan wawancara terhadap Jero Bendesa adat Kuta yang tinggal di Kuta yang memahami tentang simbol-simbol suci agama Hindu dan penggunaan simbol-simbol suci agama Hindu dalam bentuk tato sebagai informan pangkal dan seniman tato yang memahami tentang tato, bentuk tato dan penggunaan simbol -simbol suci agama Hindu dalam bentuk tato sebagai informan kunci. Teknik Analisis data yang dipakai dalam penelitian ini adalah deskriptif kualitatif.

Deskriptif kualitatif yaitu suatu cara analisis data yang dilakukan secara sistematis, actual, dan akurat mengenai fakta-fakta yang ada sehingga diperoleh suatu kesimpulan. Analisis ini digunakan untuk menguraikan hasil 
informasi yang diperoleh dari seniman tato, Jero Bendesa adat Kuta, Pemangku, masyakat lokal dan wisatawan yang menggunakan jasa tato di Kuta. Untuk mengetahui dan memperoleh gambaran yang jelas dan objektif mengenai komodifikasi simbol-simbol suci agama hindu sebagai produk industri kreatif dalam bentuk tato.

\section{HASIL DAN PEMBAHASAN \\ Bentuk Simbol-Simbol Suci Agama Hindu}

Simbol-simbol suci agama Hindu adalah fakta kebudayaan yang wujudnya berbentuk benda (tangible) atau non benda (intangible). Tetapi agama bukanlah kebudayaan, karena agama berada dalam tataran abstrak (bhatin) yang inti dan sifatnya berhubungan dengan kepercayaan (shadha). Manifestasi kepercayaan agar benar-benar tampak nyata itulah cara bagaimana menjalankan suatu agama, yang diantaranya dapat melahirkan simbol-simbol suci agama. (Widana, 2017)

Berbagai bentuk simbol-simbol suci agama Hindu bermanfaat sebagai media untuk mendekatkan diri dengan Tuhan Yang Maha Esa. Berbagai simbol-simbol suci agama dari bentuk dan bahannya yang sangat sederhana sampai yang sangat kompleks dapat dijumpai penjelasan atau keterangannya dalam kitab suci Veda dan susastra Hindu termasuk pula dalam berbagai lontar-lontar suci (Widana, 2017).

Bentuk simbol-simbol suci agama Hindu, tidak terlepas dari konsepsi penggambaran Tuhan Yang Maha Esa, yakni gambaran seperti manusia, binatang, separo manusia dan binatang, tumbuh-tumbuhan, separo manusia dan separo tumbuh-tumbuhan, benda-benda langit, huruf-huruf dan bahkan sarana persembahan seperti daksina merupakan perwujudan dewa-dewa atau dewi-dewi dan manifestasi dari Tuhan Yang Maha Esa.

Adapun bentuk-bentuk simbol-simbol suci agama Hindu yang menggambarkan Tuhan Yang Maha Esa, sebagai berikut:

\section{Berbentuk Manusia Dengan Kelebihannya}

Simbol suci agama Hindu ini berbentuk manusia dengan kelebihannya seperti bertangan empat, delapan atau dua belas, berkaki tiga, bermata tiga dan lain- lain. Penggunaan simbol manusia baik laki-laki dan perempuan, atau separuh laki-laki separuh perempuan (ardhanarisvari) terutama ditunjukan kepada para devata baik dewa-dewa maupun dewidewi, termasuk pula para pengiringnya Apsara-
Apsari atau Vidyadhara dan Vidyadhari, penari dan pemusik khayangan seperti para KinnaraKinnari, juga untuk para leluhur laki-laki maupun perempuan. (Titib, 2001: 67)

Dalam hal tertentu, sebagai Ardhanarisvari yakni Tuhan Yang Maha Esa yang digambarkan sebagai separuh laki-laki dan perempuan, karena sesungguhnya Tuhan Yang Maha Esa tidak laki -laki dan tidak perempuan. Demikian juga separuh badan terbelah dari kepala ke kaki berwujud dewa Siva dan seapruhnya berwujud dewa Visnu. Penggambaran ini ditunjukan kepada aspek Tuhan Yang Maha Esa yang disebut Harihara (Siva dan Visnu dalam satu badan). Demikian pula Acintya yang mengandung arti tak terpikirkan digambarkan juga sebagai Manusi telanjang yang mengangkat kaki kirinya dan setiap sendi mengeluarkan cahaya (aura) yang menunjukan kedekatan Sivanattyaraja, yakni dewa Siva sebagai rajanya para penari. (Titib, 2001: 68)

Penggambaran simbol-simbol sebagai arca dewa-dewa atau Citradevata diatur dalam Kitab Silpasastra, namun kenyataannya di Bali tidak semua arca devata sesuai dengan ketentuan tersebut, hal ini dimungkinkan karena memang terbatasnya membaca sumbersumber tersebut atau didorong oleh naluri seni yang kadang-kadang mengabaikan ketentuan yang telah dibakukan. Seperti contoh, penggambaran wajah para devata selalu muda, karena mereka meminum amrta, mengakibatkan tidak kenal usia tua (nirjana), namun di Bali untuk penggambaran dewa Siva sebagai Mahayogi sering wajah beliau digambarkan sebagai wajah orang tua. Simbol suci agam Hindu berbentuk manusia dengan segala kelebihannya pada Tabel 1 .

Berdasarkan Tabel 1 dapat dijelaskan bahwa terdapat beberapa bentuk simbol suci agama Hindu yaitu manusia dengan segala kelebihannya seperti bertangan 4 yang digambarkan dengan Dewi Saraswati. Dewi Saraswati dalam agama Hindu dilambangkan dengan gadis cantik berkulit putih dan bertangan empat yang masing-masing tangannya menggenggam benda yang berbeda. Tangan pertama menggenggam lontar (kitab suci Veda) yang melambangkan pengetahuan yang universal, abadi dan ilmu pengetahuan yang sejati. Tangan kedua menggenggam genitri yang melambangkan ilmu spiritual dan meditasi. Tangan ketiga damaru (kendang kecil) dan tangan keempat menggenggam wina 
(kecapi) melambangkan kesempurnaan seni dan pengetahuan.

Tabel 1. Simbol Suci Agama Hindu Berbentuk Manusia

\begin{tabular}{ll}
\hline Jenis & Bentuk \\
\hline $\begin{array}{l}\text { Manusia Berkepala Empat } \\
\text { (Dewa Brahma) }\end{array}$ \\
\hline $\begin{array}{l}\text { Manusia Bertangan Empat } \\
\text { (Dewi Saraswati) }\end{array}$ \\
\hline $\begin{array}{l}\text { Manusia Bertangan Sepuluh } \\
\text { (Dewi Durga) }\end{array}$
\end{tabular}

Sumber: Titib, 2001.

Selain bertangan 4 , adapula digambarkan dengan manusia bertangan 10 yang digambarkan dalam wujud Dewi Durga (Uma). Dewi Durga dalam agama Hindu merupakan lambang dari kekuatan Yang Maha Tinggi yang mempertahankan tataran kebenaran dan moral. Dilambangkan dengan dewi yang cantik dengan raut wajah penuh rasa amarah dengan 10 tangan dan menggenggam benda yang berbeda.

Simbol suci Agama Hindu Manusia dengan segala kelebihannya di lambangkan dengan Dewa Brahma. Yang digambarkan sebagai dewa berkepala 4. Dewa Brahma dalam ajaran agama Hindu dikenal sebagai Dewa Pencipta. Dewa Brahma digambarkan dengan pria tua berjenggot putih dan berkepala empat yang menghadap ke 4 penjuru arah mata angin serta bertangan 4 yang memegang alat-alat sebagai berikut: 1) Aksmala/tasbih yang melambangkan tiada awal dan tiada akhir, 2) Sruk (sendok besar) dan surva (sendok biasa) yang melambangkan upacara yadnya, 3) Kamandalu (kendi) melambangkan keabadian, 4) Pustaka yang melambangkan ilmu pengetahuan.

\section{Bentuk Binatang}

Simbol suci agama Hindu berbentuk binatang seperti Barong Ket di Bali merupakan simbol Dewa Siva, Barong Bangkung adalah
Dewa Visnu ketika Ia mengejar ujung Lingga Kristal (Sphatikalingga) yang masuk ke dalam bumi. Demikian pula wujudnya sebagai burung garuda yang di dalam kitab suci Reg Veda disebut Garutmat, sebagai burung berwarna keemasan yang menurunkan hujan, menganugrahkan kemakuran kepada umat-Nya.

Berdasarkan wawancara bersama Bapak Made Selamet selaku Pemangku Pura Penyarikan Kuta menyatakan bahwa:

"simbol suci berbentuk binatang seperti Burung Garuda yang merupakan kendaraan (wahana) Dewa Wisnu, tikus kendaraan Dewa Ganesha, Angsa kendaraan Dewa Brahma, lembu kendaraan Dewa Siwa, Naga Basuki yang merupakan wujud (manifestasi) Dewa Wisnu, Naga Tasaka wujud (manifestasi Dewa Siwa yang menjaga bumi dilangit dalam bentuk atmosfir, Naga Ananthabhoga merupakan wujud Dewa Brahma yang memeluk bumi", (Wawancara, 20/09/2019).

Berdasarkan hasil wawancara bersama pemangku Kuta di jelaskan bahwa wujud lain adalah sebagai Naga Taksaka yang di dalam Sivagama di Bali merupakan wujud Sang Hyang Siva yang menjaga bumi di langit dalam bentuk atmosfir. Demikian pula naga Anantabhoga merupakan wujud Sang Hyang Brahma yang memluk ini bumi (berupa kulit bumi) yang menganugrahkan makanan tiada akhirnya. Naga Vasuki adalah wujud Sang Hyang Visnu berupa air di muka bumi, ekornya terletak di lereng pegunungan dan kepalanya berada di tengah lautan luas. Di samping sebagai simbol wujud dewa-dewi, juga sebagai "wahana" (kendaraan) dari para devata, misalnya garuda wahana dewa Visnu, lembu wahana dewa Siwa, angsa kendaraan dewa Brahma, burung merah kendaraan dewa Kumara atau Subramanyam, tikus kendaraan dewa Ganesha dan lain-lain. Binatang juga diyakini sebagai binatang peliharaan kesenangan para Devata, seperti misalnya bentuk "pecanangan" (tempat sirih) yang digambarkan sebagai singa bersayap, harimau putih, ular bersayap dan lain-lain. Bentuk simbol suci agama Hindu dalam bentuk binatang dapat dilihat dalam Tabel 2 . 
Tabel 2. Simbol Suci Agama Hindu Dalam Bentuk Binatang

\begin{tabular}{l}
\hline \multicolumn{1}{c}{ Jenis } \\
Burung Garuda \\
(Kendaraan Dewa Wisnu) \\
\hline Barong \\
Naga Basuki \\
(wujud Sang Hyang Wisnu) \\
Naga Anantabogha \\
Bujud Sang Hyang
\end{tabular}

Sumber: Titib, 2001.

Berdasarkan Tabel 2 simbol suci agama Hindu dalam bentuk binatang digambarkan dalam wujud burung garuda, barong, naga anantaboga, naga basuki dan rangda. Dalam ajaran agama Hindu, burung garuda merupakan kendaraan dari Dewa Wisnu. Dalam mitologi agama Hindu burung garuda merupakan anak dari Bagawan Kasyapa yang memiliki 2 orang istri. Burung garuda sendiri merupakan anak dari Winata. Selain Burung garuda, simbol suci agama Hindu dalam bentuk binatang disimbolkan dengan Barong. Dalam Bahasa Sansekerta yaitu B(h)arwang, dalam Bahasa Indonesia beruang yang berarti penjaga hutan. Dalam ajaran agama Hindu barong merupakan lambang dari kebajikan (Dharma).

Naga Anantaboga dalam ajaran agama Hindu merupakan pewujudan dari dewa Brahma yang dilambangkan dengan naga yang besar. Sang Hyang Anantaboga merupakan peruwujudan dewa yang berstana di lapisan bumi ketujuh. Selain naga Anantaboga, naga basuki juga merupakan simbol suci agama Hindu dalam bentuk binatang. Naga basuki merupakan perwujudan dari Dewa Wisnu. Naga Basuki merupakan simbol dari keseimbangan siklus yang terjadi di alam.

Rangda dalam ajaran agama Hindu merupakan lawan dari Barong. Barong dan Rangda merupakan lambang dari Rwabinedha (kebaikan dan kejahatan). Rangda dilambangkan dengan wanita yang berambut panjang acak-acakan, kuku panjang, lidah yang menjulur panjang dan payudayara yang panjang serta wajah yang menyeramkan dengan taringtaring yang panjang dan tajam. Rangda dalam ajaran agama Hindu dikenal sebagai ratu dari para leak (orang yang memiliki ilmu hitam).

\section{Berbentuk Separuh Manusia dan Separuh Binatang}

Simbol suci dalam bentuk separuh manusia dan separuh binatang seperti Ganesha putra Sang Hyang Siva yang lahir dari Dewi Uma. Dewa Hayagriva yang berbadan manusia berkepala kuda. (Widana, 2019). Bentuk simbol suci agama Hindu Dalam bentuk Manusia berkepala binatang dapat dilihat dalam Tabel 3 .

Tabel 3 Simbol Suci Agama Hindu Manusia Berkepala Binatang

\begin{tabular}{lc}
\hline Jenis & Bentuk \\
\hline Dewa Ganesha & \\
&
\end{tabular}

Sumber: Titib, 2001

Berdasarkan Tabel 3 diketahui bahwa simbol suci agama Hindu Manusia Berkepala Binatang digambarkan dengan wujud Dewa Ganesha yang dilambangkan dengan seorang pria laki-laki berkepala gajah dan berperut buncit.

\section{Berbentuk Manusia Berkepala Tumbuh-Tumbuhan}

Simbol suci manusia berkepala tumbuhtumbuhan contohnya pohon Soma, Pohon Kha danlain-lain. Namun simbol seperti ini hampir tidak dikenal di Bali.

\section{Berbentuk Benda Atau Huruf Tertentu}

Simbol suci agama Hindu dalam bentuk benda atau huruf misalnya matahari atau cakram (roda) simbol dari Sang Hyang Surya, 
bulan simbol dari Dewi Chandra, huruf Omkara simbol dari Tuhan Yang Maha Esa. Um simbol Dewa Visnu, Am simbol Dewa Siva. Garis-garis tertentu seperti Swastika, teratai, permata, Sphatika, mirah delima dan lain-lain. Air suci sebagai devata, misalnya air sungai gangga merupakan perwujudan dari Dewi Gangga. Canang "pelinggih" sebagai stana devata, daksina sebagai wujud atau pelinggih devata. (Widana, 2019)

Demikian antara lain bentuk-bentuk simbol suci dan bentuk simbol suci agam Hindu yang tidak terlepas dari arti dan makna simbol suci tersebut dalam kehidupan Umat Hindu. Bagi umat Hindu semua bentuk simbol menimbulkan getaran batin dalam dirinya, dirasakan dan diyakini sebagai sarana mendekatkan diri dengan Tuhan Yang Maha Esa. Dapat dilihat pada Tabel 4.

Tabel 4. Simbol Suci Agama Hindu Dalam Bentuk Huruf dan Benda Langit

\begin{tabular}{|c|c|}
\hline Jenis & Bentuk \\
\hline $\begin{array}{l}\text { Om Kara } \\
\text { (Versi Hindu Bali) }\end{array}$ & \\
\hline $\begin{array}{l}\text { Cakra } \\
\text { (Lambang Matahari) }\end{array}$ & \\
\hline
\end{tabular}

Sumber: Mantra Hindu, 2019.

Berdasarkan Tabel 4. diketahui bahwa simbol suci agama Hindu dalam bentuk huruf dan benda langit dilambangkan dalam bentuk Om Kara dan cakra. Om Kara merupakan simbol dari Tuhan Yang Maha Esa. Di Bali $\mathrm{Om}$ Kara peratama kali diperkenalkan oleh Rsi Kuturan. Selain Om Kara, simbol suci agama Hindu dalam benda langit yaitu cakra. Dalam ajaran agama Hindu cakra merupakan senjata dari Dewa Wisnu.

\section{Fungsi Simbol-Simbol Suci Agama Hindu}

Di India, sebuah simbol suci agama atau arca difungsikan sebagai media pemujaan bila telah melaksanakan Sodasopacara (16 macam rangkaian upacara). Simbol-simbol suci ini dapat digunakan setelah dilakukan proses sakralisasi yang disebut "prayascitta" dengan urutan upacaranya seperti: memohon kehadiran-Nya (Avahana), mempersembahkan stana-Nya (Asana), mempersembahkan air pencuci kaki (Padnya), persembahan air (Arghya), penyucian (Snana), persembahan pakaian (Wastra), persembahan benang tali suci/di Bali dengan mantram Sivasutram, persembahan bubuk kayu cendana (Candana/Bhasma), persembahan bunga, merupakan cerminan kesucian hati (Puspa), persembahan api dengan asapnya yang berbau harum (Dupha), persembahan api/mohon peneranagn jiwa (Dipa), persembahan makanan (Naivedya), persembahan sirih, di Bali disebut porosan (Tambulam), dan saat itu pula umat mempersembahkan persembahan bunga dengan cakupan tangan (Puspanjali) dan diakhiri dengan penutup persembahyangan, di Bali disebut Ngeluhur (Visarjana), setelah sebelumnya memohon air suci kehidupan atau Tirtha (Amrta). (Titib, 2001: 71)

Hasil wawancara di lapangan bersama Bapak Made Selamet selaku Pemangku Pura Penyarikan Kuta yang menyatakan bahwa:

"Simbol agama Hindu yang dibuat oleh undagi dan seniman atau yang langsung terjadi secara alamiah tidak langsung bisa dikatakan sebagai simbol suci agama Hindu yang bernilai sakral apabila belum diupacarai. Uparacara penyakralan itu di sebut dengan "pasupati". Setelah di pasupati barulah simbol itu bisa dikatakan sebagai benda yang memiliki nilai suci. Kesucian sebuah simbol agama juga dipengaruhi oleh sradha dan bhakti umatNya", (Wawancara, 20/09/2019).

Berdasarkan hasil wawancara bersama mangku di Kuta, setelah terwujudnya sebuah atau lebih beberapa simbol, baik yang langsung terjadi secara alamiah, atau yang sengaja dibentuk oleh undagi, sangging atau seniman tidak dapat langsung dikatakan sebagai simbol suci. Benda atau simbol dapat dikatakan sebagai benda atau simbol suci apabila telah dilakukan sakralisasi dengan berbagai rangkaian upacara agama. Penyakralan atau penyucian simbol-simbol agama di sebut dengan masupati yang berasal dari Bahasa sansekerta yaitu "Pasupati". Pasupati adalah salah satu nam dari Sang Hyang Siva yang pada mulanya berrati dewa bagi binatang ternak, selanjutnya dalam ajaan Saiva siddhanta, Kata Pasupati mengandung makna Tuhan Yang 
Maha Esa sebagai pimpinan seluruh makhluk hidup, termasuk umat manusia.

Upacara Masupati mengandung makna menghidupkan simbol-simbol yang sebelumnya belum disucikan. Setelah disucikan dengan upacara penyucian yang berisikan sesajen "Prayascitta", maka dilanjutkan dengan upacara memfungsikan simbo,-simbol yang telah disucikan tersebut. Sebuah simbol akan mejadi sangat suci apabila umat-Nya dengan Sraddha dan Bhakti yang tulus. Benda yang dijadikan simbol suci tersebut akan menjadi daya spiritual yang tinggi.

Simbol-simbol suci agama Hindu tersebut pada umumnya berfungsi sebagai sarana untuk memuja kebesaran atau keagungan-Nya. Dengan demikian simbolsimbol suci agama Hindu ini berfungsi untuk memantapkan Sraddhha (keimanan), Bhakti (ketaqwaan) umat beragama. Berdasarkan uraian diatas, maka fungsi simbol antara lain:

1. Meningkatkan dan memantapkan Sraddha (keimanan atau keyakinan mendalam) umat dalam rangka menumbuhkan Bhakti (ketaqwaan), yang akan membentuk kepribadian umat manusia dengan moralitas yang tinggi yang pada akhirnya akan meningkatkan akhlak luhur masyarakat.

2. Menumbuh kembangkan dan tetap terpeliharanya nilai seni budaya baik melalui seni arca, seni lukis dan seni kriya lainnya yang mengacu kepada kitab Silpasastra, sehingga arca atau simbol yang dibuat tidak menyalahi ketentuan kitab Silpasastra.

3. Memupuk rasa kebersamaan dikalangan umat Hindu dalam mewujudkan sarana pemujaan, yang utama dalam kaitan dengan sakralisasi dan memfungsikan simbolsimbol yang dibuat.

Dengan rangkaian upacara agama maka sebuah simbol tidak lagi merupakan benda mati, namun menjadi benda hidup yang memiliki fungsinya masing-masing. Simbolsimbol suci yang telah disakralisasi tidak lagi sesuatu benda biasa, tetapi sesuatu yang hidup, mengadung daya spiritual guna memantapkan Sraddah dan Bhakti umat Hindu yang menggunakan sarana tersebut. Terdapat berbagai variasi dan rangkaian upacara memfungsikan sebuah simbol. Semakin sederhana fungsi simbol tersebut, maka upacara untuk hal tersebut juga semakin sederhana.
Pada Tabel 5 dapat dilihat fungsi dari simbol suci agama Hindu yang bernilai sakral, sebagai berikut:

Tabel 5. Fungsi Simbol Suci Agama Hindu

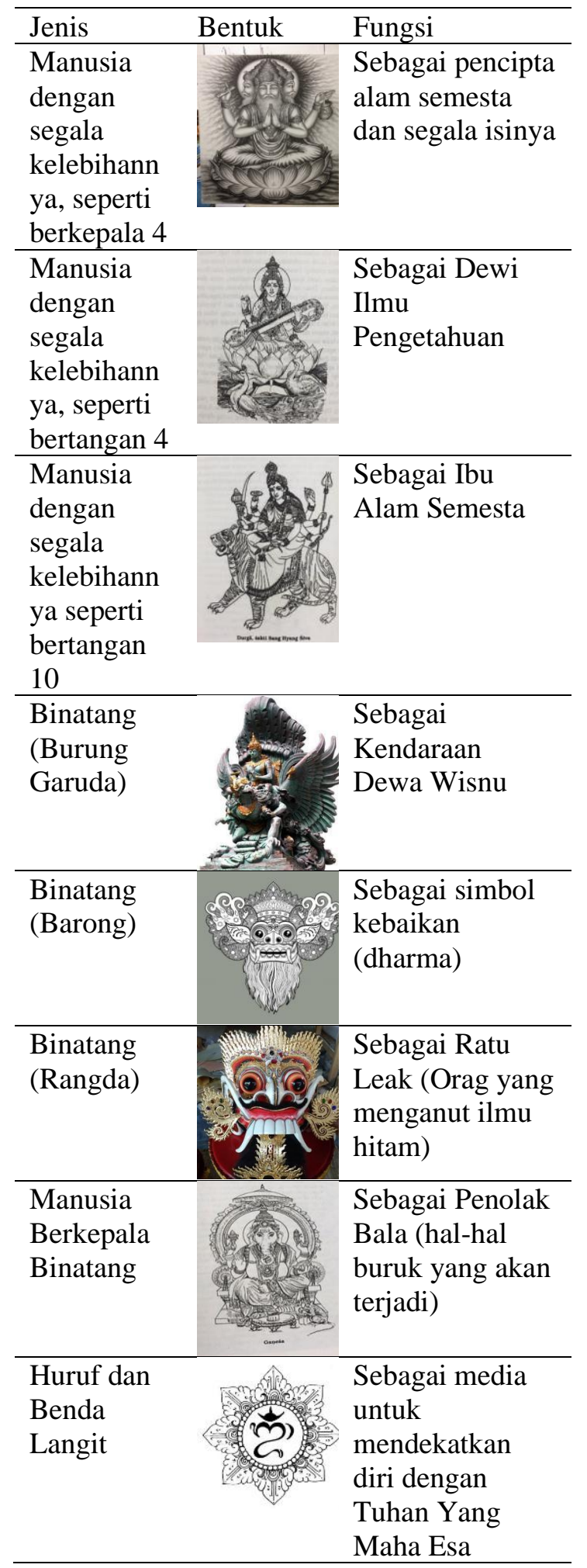




\begin{tabular}{|c|c|}
\hline $\begin{array}{l}\text { Huruf dan } \\
\text { Benda } \\
\text { Langit }\end{array}$ & $\begin{array}{l}\text { Sebagai Senjata } \\
\text { Dewa Wisnu }\end{array}$ \\
\hline
\end{tabular}

Sumber: Titib, 2001.

Berdasarkan Tabel 5 dapat dijelaskan fungsi dari simbol agama Hindu. Simbol agama Hindu Manusia dengan segala kelebihannya seperti berkepala empat di gambarkan dalam wujud Dewa Brahma. Dewa Brahma merupakan bagian dari Tri Murti. Fungsi Dewa Brahma yaitu sebagai Dewa Pencipta Alam Semesta beserta segala isinya. Dalam bentuk manusia dengan segala kelebihannya yaitu bertangan empat digambarkan dengan Dewi cantik yang berkulit putih mulus yaitu Dewi Saraswati. Dalam ajaran agama Hindu Dewi Saraswati memiliki fungsi sebagai Dewi Ilmu Pengetahuan. Selanjutnya Manusia bertangan 10 diwujudkan dalam sosok Dewi Cantik yang wajahnya penuh dengan rasa amarah yaitu Dewi Durga. Dewi Durga memiliki fungsi sebagai ibu alam semesta.

Simbol suci agama Hindu dalam bentuk binatang pada Tabel diatas digambarkan dengan Burung Garuda, Barong dan Rangda. Burung Garuda memiliki fungsi sebagai kendaraan Dewa Wisnu. Barong merupakan salah satu simbol suci agama Hindu yang berfungsi sebagai simbol kebajikan (dharma). Kemudian simbol suci agama Hindu dalam bentuk Binatang yaitu Rangda yang memiliki fungsi sebagai ratu dari leak (penganut ilmu hitam).

Dalam bentuk Manusia berkepala binatang di gambarkan dalam wujud Dewa Ganesha. Dewa Ganesha yaitu dewa yang memiliki fungsi sebagai penolak bala (hal-hal buruk yang terjadi). Selanjutnya yaitu simbol suci agama Hindu dalam bentuk huruf dan benda langit berdasarkan Tabel diatas ada 2 yaitu Om Kara dan Cakra. Om Kara memiliki fungsi sebagai Media untuk mendekatkan diri kepada Tuhan Yang Maha Esa. Cakra memiliki fungsi sebagai senjata dari Dewa Wisnu.

\section{Makna Simbol-Simbol Suci Agama Hindu}

Simbol suci agama merupakan lambang yang dimiliki suatu agama untuk menggambarkan TuhanYang Maha Esa. Selain itu simbol juga dijadikan sebagai sarana dan prasarana uapacara keagamaan. Setiap agama pasti memiliki simbol peribadatannya masing- masing. Seperti halnya agama Hindu yang memiliki simbol suci agama yang dijadikan sebagai media untuk mendekatkan diri kepada Ida Sang Hyang Widhi Wasa.

Dalam ajaran agama Hindu, simbol suci agama memiliki makna yang sakral dan suci. Setiap simbol memiliki maknanya masingmasing. Adapun makna dari simbol-simbol suci agama Hindu dapat dilihat pada Tabel 6.

Tabel 6. Makna Simbol-Simbol Suci Agama Hindu

\begin{tabular}{|c|c|c|}
\hline Jenis & Bentuk & Makna \\
\hline $\begin{array}{l}\text { Manusia } \\
\text { Berkepala } 4 \\
\text { (Dewa } \\
\text { Brahma) }\end{array}$ & & $\begin{array}{l}\text { Sebagai } \\
\text { kesadaran dan } \\
\text { kesucian }\end{array}$ \\
\hline $\begin{array}{l}\text { Manusia } \\
\text { Bertangan } 4 \\
\text { (Dewi } \\
\text { Saraswati) }\end{array}$ & & $\begin{array}{l}\text { Sebagai Ilmu } \\
\text { Pengetahuan } \\
\text { yang Sejati }\end{array}$ \\
\hline $\begin{array}{l}\text { Manusia } \\
\text { Bertangan } \\
10 \\
\text { (Dewi } \\
\text { Durga) }\end{array}$ & & $\begin{array}{l}\text { Sebagai } \\
\text { kekuatan dalam } \\
\text { mengalahkan } \\
\text { hal-hal negatif }\end{array}$ \\
\hline $\begin{array}{l}\text { Binatang } \\
\text { (Burung } \\
\text { Garuda) }\end{array}$ & & $\begin{array}{l}\text { Sebagai } \\
\text { kekuatan atau } \\
\text { keperkasaan }\end{array}$ \\
\hline $\begin{array}{l}\text { Binatang } \\
\text { (Barong) }\end{array}$ & & $\begin{array}{l}\text { Sebagai } \\
\text { Kebenaran } \\
\text { (dharma) }\end{array}$ \\
\hline $\begin{array}{l}\text { Binatang } \\
\text { (Rangda) }\end{array}$ & & $\begin{array}{l}\text { Sebagai } \\
\text { Adharma (hal- } \\
\text { hal yang } \\
\text { berhubungan } \\
\text { dengan ilmu } \\
\text { hitam) }\end{array}$ \\
\hline $\begin{array}{l}\text { Manusia } \\
\text { berkepala } \\
\text { binatang } \\
(\text { Dewa } \\
\text { Ganesha) }\end{array}$ & & $\begin{array}{l}\text { Sebagai } \\
\text { Kecerdasan }\end{array}$ \\
\hline
\end{tabular}




\begin{tabular}{lll}
\hline Berbentuk & Sebagai Tuhan \\
Huruf & Om Kara $)$ & Yang Maha Esa \\
& (On) & Dan Ang, Ung, \\
& Mang & (Tri Murti) \\
\hline
\end{tabular}

Sumber: Titib, 2001.

Berdasarkan Tabel 6 dapat dijelaskan bahwa setiap simbol memeliki maknanya masing-masing. Seperti makna dari Dewa Brahma yaitu sebagai kesadaran dan kesucian. Makna simbol dewa Brahma mengandung nilai mistis-spiritual simbolis. Dewa Brahma duduk bersthana diatas bunga Padma (lotus) menunjukan bahwa Ia adalah asal muasal dari kenyataan yang tidak terbatas. Padma adalah lambang dari kenyataan yang sejati yang merupakan perwujudan-Nya. Lotus melambangkan alam semesta, bunga yang terbentang dalam semua bentuk keagungannya, yang tiada berwujud dan tiara berakhir. Lotus juga melambnagkan kesucian, karena Tuhan Yang Maha Esa bersthana pada yang suci, yang disimbolkan dengan bunga Padma (lotus).

Dewi Saraswati dilambangkan dnegan wanita cantik yang memiliki kulit putih bersih, perilakunya lemah lembut. Digambarkan dengan busana putih gemerlap dan berdiri diatas bunga teratai, memiliki empat tangan yang masing-masing menggenggam benda yang berbeda. Atribut dewi Saraswati dilengkapi dengan angsa dan merak. Makna dari simbol dewi Saraswati adalah sebagai berikut:

1. Dewi yang cantik berkulit putih mulus melambangkan ilmu pengetahuan yang menarik umat manusia, murni, dan meningkatkan keseluruhan hidup dan budhi pekerti.

2. Bertangan 4 melambangkan penguasa kitab suci Veda (Catur Veda) dan penguasaan alam semesta.

3. Masing-masing tangan menggenggam: kecapi melambangkan keindahan, genitri melambangkan ilmu spiritual dan meditasi, lontar melambangkan ilmu universal dan abadi, keropak lambang pengetahuan.

4. Merak melambangkan ego, bagi seorang yang bijak agar egonya ditekan tidak diberikan menguasi dirinya.

5. Angsa melambangkan kebijaksanaan dan mampu membedakan yang baik dan buruk.

Dewi Durga merupakan ibu dan dewi alam semesta. Dewi durga digambarkan dalam wujud wanita cantik dengan wajah penuh amarah. Dewi durga dalam mitoligi Hindu memiliki makna menundukan sifat-sifat keraksaksaan yang terdapat pada diri manusia. Lambang senjata yang ada pada tangan dewi Durga melambangkan kekuasaan para dewa mengalahkan sifat-sifat negatif umat manusia.

Burung Garuda merupakan kendaraan dewa Wisnu. Makna dari burung garuda yaitu dilihat dari perwujudan burung yang gagah dan perkasa yang melambangkan kekuatan. Selanjutnya makna dari Barong dalam agama Hindu yaitu sebagai pemberantas hal-hal negatif dan penolak bala (bahaya). Rangda memiliki makna sebagai kekuatan yang bersifat negatif. Barong dan Rangda merupakan gambaran dari rwabinedha (kebaiakn dan keburukan). Dalam mitologi Hindu barong digambarkan sebagai hal yang bersifat dharma (baik) dan rangda adharma (buruk).

Dewa Ganesha digambarkan dalam wujud pria dengan kepala gajah dan berperut buncit. Dewa Ganesha memiliki makna sebagai kecerdasan dan penolak bala (hal-hal buruk). Simbol suci agamHindu dalam bentuk huruf digambarkan dalam bentuk Om Kara. Om Kara merupakan lambang Tuhan Yang Maha Esa. Makna dari Om Kara yaitu aksara tunggal AUM (OM) sebagai 3 aspek Tuhan (Brahma, Wisnu, Siwa).

\section{Bentuk, Fungsi dan Makna Simbol Suci Agama Hindu Dalam Tato}

Simbol suci agama Hindu merup hj akan sebuah benda atau hal sakral yang memiliki nilai dan makna serta fungsi yang suci setelah disakralisasi dengan rangakian upacara keagamaan. Simbol suci agama Hindu ini di fungsikan sebagai sarana untuk meningkatkan dan memantapkan keimanan, keyakinan serta ketaqwaan umat agama terhadap Tuhan Yang Maha Esa.

Namun dengan semakin berkembangnya zaman dan globalisasi menyebabkan terjadinya komodifikasi terhadap budaya termasuk simbol-simbol agama. Hal tersebut tidak terlepas dari adanya perkembangan pariwisata dan permintaan wisatawan. Untuk memenuhi permintaan wisatawan para pelaku wisata melakukan berbagai cara, salah satunya dengan mengkomodifikasi simbol suci agama menjadi sebuah peluang bisnis. Dalam penelitian ini peluang bisnis dengan memanfaatkan simbol suci agama di lakukan dengan mengkomodifikasi simbol agama dalam bentuk tato. 
Berdasarkan hasil wawancara di lapangan bersama Bapak Mangku Suta selaku seniman tato temporary di Pantai Kuta, menyatakan bahwa:

"Saya sudah lama menjadi seniman tato temporary ini, sudah dari tahun 2007. Jenis tato yang paling disukai wisatawan itu bungabunga. Tapi ada juga wisatawan yang meminta tato dengan simbol agama seperti salib, om kara, ganesha, dan yinyang. Kalo tato simbol agama saya izinkan dengan syarat tatonya harus di tangan atau di punggung. Kalo di bagian tubuh lain apalagi di bagian bawah say atolak dengan penjelasan kalau simbol itu merupakan simbol agama yang suci (Wawancara, 14/09/2019).

Berdasarkan hasil wawancara tersebut diketahui bahwa komodifikasi simbol suci agama Hindu dalam bentuk tato ini sudah terjadi dalam jangka waktu yang lama. Dalam komodifikasi simbol agama Hindu sebagai tato tetap memperhatikan kesucian dari simbol tersebut, hal itu dibuktikan adanya pembagian tubuh yang bisa di tato simbol agama adalah bagian tubuh atas seperti tangan, punggung dan adanya penjelasan tentang nilai dari simbol agama tersebut. Adapun simbol-simbol suci agama Hindu yang dijadikan sebagai tato, yaitu: Simbol Om Kara, Dewa Ganesha, Barong dan Rangda.

Berdasarkan hasil wawancara dengan Bapak Kadek Bagus selaku seniman tato permanent di Kuta menyatakan bahwa:

"Kalau ada wisatawan yang mau ditato dengan simbol suci agama di anggota tubuh saya izinkan tapi bagian bawah seperti pinggul, paha dan kaki tidak boleh. Saya akan menolak dengan cara menjelaskan arti dari simbol tersebut dan saya bilang simbol agama itu membawa keberuntungan. Biasanya wisatawan ngerti dan mau nurutin apa kata saya, walau kadang ada juga yang maksa tapi ya saya tolak baik-baik danmerekomendasikan tato dengan gaya lain (Wawancara, 14/09/2019).

Berdasarkan wawancara tersebut dapat diketahui bahwa tato dengan simbol suci agama Hindu tidak dapat digunakan pada tubuh bagian bawah, karena menurut seniman tato di kuta simbol tersebut merupakan simbol suci yang letak penempatan tatonya harus dianggota tubuh bagian atas. Seniman tato juga menjelaskan arti dari simbol tersebut kepada wisatawan. Wawancara selanjutnya bersama Bapak Wayan Wasista selaku Jero Bendesa Adat Kuta menyatakan bahwa:

"Menurut saya simbol suci agama Hindu itu memang merupakan benda sakral yang memiliki makna dan fungsi yang suci. Saya juga tau adanya penggunaan simbol suci sebagai tato bahkan bukan hanya tato ada juga patung, accesoris dengan lambang agama Hindu dan lain sebagainya, ya tapi karna belum ada aturan dari pemerintah tentang penggunaan simbol agama sebagai souvernir dan tato menyebabkan komodifikasi tersebut tidak dapat dihentikan, apalagi tato di kuta sudah ada sejak tahun 80an jadi susah untuk mengehentikan itu. Dan masyarakat juga tidak pernahmengeluhkan hal itu, dalam rapat juga tidak pernah ada pembahasan mengenai penggunaan simbol agama pada tato (Wawancara, 11/09/2019).

Berdasarkan hasil wawancara tersebut diketahui komodifikasi terhadap simbol-simbol suci agama Hindu dalam bentuk tato terjadi karena belum adanya aturan yang mengatur atau melarang penggunaan simbol suci agama Hindu sebagai tato maupun souvenir. Menurut Beliau, selama ini belum pernah ada keluhan masyarakat tentang komodifkasi tersebut dan belum pernah ada pembahasan mengenai penggunaan simbol suci agama dalam bentuk tato di Desa Kuta. Sehingga penggunaan simbol suci agama Hindu dalam bentuk tato ini tetap berjalan dan berkembang hingga saat ini.

Wawancara berikutnya bersama Bapak Jero Mangku Made Selamet selaku Jero Mangku Penyarikan menyatakan bahwa:

"Komodifikasi simbol suci agama Hindu dalam bentuk tato tidak seharusnya terjadi. Simbol suci merupakan hal yang bernilai sakral dan tidak seharusnya dijadikan sebagai peluang bisnis. Simbol suci menurut ajaran agama Hindu seharusnya diletakan dan dipergunakan di tepat yang suci seperti Pura, Merajan atau tempat-tempat suci lainnya. Karena simbol suci tersebut berfungsi sebagai sarana atau media untuk meningkatkan keyakinan dan ketaqwaan umat kepada Tuhan Yang Maha Esa", (Wawancara, 11/09/2019)

Berdasarkan hasil wawancara tersebut diketahui bahwa simbol suci agama Hindu itu bernilai sakral dan tidak seharusnya dijadikan 
sebagai peluang bisnis. Fungsi dari simbol agama Hindu adalah sebagai media untuk meningkatkan ketaqwaan dan keyakinan umat terhadap Tuhan Yang Maha Esa. Sebaiknya simbol suci agama tersebut diletakan di merajan atau di tempat suci.

Wawancara selanjutnya bersama Ibu Made Nita selaku masyarakat lokal yang tinggal di Kuta menyatakan:

"Komodifikasi simbol suci agama Hindu dalam bentuk tato tidak salah selama tato tersebut dibuat di anggota tubuh bagian atas seperti tangan, leher, dada dan punggung. Tato dengan bentuk simbol suci agama tidakn hanya diminati oleh wisatawan mancanegara saja bahkan masyarakat lokal juga tertarik untuk membuat tato dengan simbol suci agama seperti simbol Ganesha, Barong dan Om Kara. Simbol suci memang merupakan benda atau hal sakral namun apabila benda tersebut belum disakralkan atau diupacarai benda tersebut hanyalah benda mati biasa yang memiliki nilai seni, seperti contoh: patung Ganesha yang dijual sebagai souvernir, tato yang ada di tubuh, gelang dan kalung dengan lambang suci dan masih banyak lagi”. (Wawancara, 11/09/2019).

Berdasarkan hasil wawancara diatas simbol suci agama Hindu bisa dikatakan sakral atau suci apabila telah disakralkan dengan rangakaian upacara agama Hindu. Dan benda yang belum disakralkan tidak bisa dikatakan sebagai benda sakral yang memiliki nilai suci, sehingga dapat di jadikan sebagai benda seni yang diperuntunkan untuk pariwisata. Seperti contoh dijadikn sebagai patung, gelang, kalung, tato dan lain sebagainya.

\section{Bentuk Komodifikasi Simbol-Simbol Suci Agama Hindu Dalam Tato}

Dalam ajaran agama Hindu dikenal 5 bentuk simbol suci agama Hindu. Simbol suci agama Hindu berbentuk manusia dengan segala kelebihannya, berbentuk binatang, berbentuk manusia berkepala binatang, berbentuk manusia berkepala tumbuhan dan berbentuk huruf atau benda-benda langit. Simbol-simbol agama Hindu tersebut hanyalah benda mati apabila belum disakralisasi dengan rangkaian upacara keagamaan.

Komodifikasi simbol suci agama Hindu dalam bentuk tato ini tidak berbeda jauh dari simbol-simbol agama yang sakral atau suci.
Bentuknya masih sama hanya aja ada sedikit variasi sesuai permintaan Wisatawan seperti variasi bunga, ukiran, garis dan lain sebagainya. Bentuk komodifikasi simbol suci agama Hindu sebagai tato dapat dilihat pada Tabel 7.

Tabel 7. Bentuk Komodifkasi Simbol-Simbol Suci Agama Hindu Dalam Tato

\begin{tabular}{|c|c|c|c|}
\hline Jenis & Bentuk & $\begin{array}{l}\text { Komodifikasi } \\
\text { Bentuk }\end{array}$ & $\begin{array}{l}\text { Bagian } \\
\text { Tubuh } \\
\text { Yang } \\
\text { Ditato }\end{array}$ \\
\hline $\begin{array}{l}\text { Tato } \\
\text { dengan } \\
\text { Simbol } \\
\text { Dewa } \\
\text { Ganesha }\end{array}$ & & $\begin{array}{l}\text { Ditambahkan } \\
\text { variasi bunga }\end{array}$ & Punggung \\
\hline $\begin{array}{l}\text { Om } \\
\text { Kara }\end{array}$ & & $\begin{array}{l}\text { Ditambahkan } \\
\text { variasi } \\
\text { seperti jam } \\
\text { tangan } \\
\text { Ditambahkan } \\
\text { variasi mata } \\
\text { Ditambahkan } \\
\text { variasi } \\
\text { lingkaran } \\
\text { Ditambahkan } \\
\text { variasi garis- } \\
\text { garis } \\
\text { Dipadukan } \\
\text { dengan } \\
\text { bunga teratai }\end{array}$ & Tangan \\
\hline $\begin{array}{l}\text { Tato } \\
\text { Barong } \\
\text { dan } \\
\text { Rangda }\end{array}$ & & & Tangan \\
\hline
\end{tabular}

Sumber: Katalog Tato Seniman Tato, 2019 
Wawancara bersama bapak Putra selaku seniman tato di Thomson's Ink menyatakan bahwa:

"Biasanya wisatawan sih suka tato dengan simbol ganehsa, karna menurut wisatawan itu menarik ada tubuh manusia tapi kepalanya gajah. Biasanya kalo tato ganesha itu di bagian punggung sama badan atas. Selain ganesha wisatawan juga tertarik sama om kara karna setelah dijelasin itu lambang Tuhan dan membawa keberuntungan jadi wisatawan mau di tato dengan simbol om kara di bagian tangan. Kalo tato dengan simbol barong dan rangda peminatnya sih orang lokal Bali, tapi ada juga beberapa wisatawan yang mau tato barong. Bagian tubuh untuk tato barong itu beragam ada di tangan, punggung, dada", (Wawancara, 14/09/2019).

Berdasarkan Tabel diatas dan hasil wawancara diketahui bahwa tato dengan simbol ganesha biasanya digunakan atau ditato pada anggota tubuh bagian punggung. Wisatawan tertarik dengan simbol ganesha karena merunut mereka simbol itu unik. Selain ganesha, wisatawan juga tertarik dengan simbol om kara. Hal tersebut dikarenakan seniman menjelaskan kepada wisatawan bahwa arti dari simbol Om kara yaitu Tuhan dan membawa keberuntungan. Untuk bagian anggota tubuh yang ditato om kara yaitu bagian tangan. Selain om kara ada juga tato barong dan rangda. Peminat tato barong dan rangda ini adalah masyarakat loka yang menyukai tato dengan simbol barong dan rangda ini. bagian tubuh yang di tato dengan simbol tersebut yaitu beragam mulai dari tangan, punggung dan dada.

Komodifikasi simbol suci agama Hindu dalam tato dan simbol suci agama dalam hal sakral memiliki bentuk yang hampir mirip. Komodifikasi terjadi pada nilai dari simbol suci tersebut. Yang awalnya simbol tersebut merupakan simbol yang memiliki nilai sakral dan suci, namun setelah dikomodifikasi maka nilainya berubah menjadi nilai komersil yang diperuntunkan untuk pariwisata.

\section{Fungsi Simbol-Simbol Suci Agama Hindu Dalam Bentuk Tato}

Dalam ajaran agama Hindu fungsi dari simbol-simbol suci tersebut memiliki fungsi yang bermakna sakral dan diperuntunkan sebagai sarana untuk mendekatkan diri Kehadapan Tuhan Yang Maha Esa. Namun setelah dikomodifikasi, simbol-simbol agama Hindu tersebut difungsikan untuk pariwisata. Dalam penelitian ini komodifikasi simbolsimbol suci agama Hindu dalam bentuk tato difungsikan untuk memenuhi permintaan wisatawan akan tato bergaya simbol suci agama hindu.

Komodifikasi ini terjadi karena adanya ketertarikan wisatawan terhadap kebudayaan Bali pada umumnya dan simbol agama Hindu pada khususnya. Sehingga pelaku wisata mengalih fungsikan simbol yang semula berfungsi sebagai sarana upacara yang bernilai sakral dan suci menjadi simbol sebagai tato yang bernilai ekonomi. Bentuk, fungsi dan makna dari simbol suci agama Hindu dapat dilihat pada Tabel 8

Tabel 8. Fungsi Simbol-Simbol Suci Agama Hindu Dalam Tato

\begin{tabular}{|c|c|c|}
\hline Jenis & Bentuk & Fungsi \\
\hline $\begin{array}{l}\text { Manusia } \\
\text { Berkepala } \\
\text { Binatang } \\
\text { (Dewa } \\
\text { Ganesha) }\end{array}$ & & $\begin{array}{l}\text { Sebagai penolak } \\
\text { bala dan } \\
\text { bencana } \\
\text { Serta berfungsi } \\
\text { sebagai seni } \\
\text { lukis tubuh }\end{array}$ \\
\hline $\begin{array}{l}\text { Huruf } \\
\text { (Om Kara) }\end{array}$ & & $\begin{array}{l}\text { Sebagai } \\
\text { Keberuntungan } \\
\text { dan seni lukis } \\
\text { tubuh }\end{array}$ \\
\hline $\begin{array}{l}\text { Binatang } \\
\text { (Barong) }\end{array}$ & & $\begin{array}{l}\text { Sebagai penolak } \\
\text { dari hal yang } \\
\text { bersifat buruk } \\
\text { dan sebagai seni } \\
\text { lukis tubuh }\end{array}$ \\
\hline
\end{tabular}

Sumber: Hasil Wawancara bersama Bapak Nengah Merti, 14/09/2019.

Berdasarkan hasil wawancara dengan Bapak Nengah Merti selaku seniman tato menyatakan bahwa:

"Tato dengan simbol ganesha memiliki makna sebagai kebajikan dan kecedasan dan berfungsi sebagai penolak bala. Simbol om kara dalam tato memiliki makna Tuhan Yang Maha Esa dan berfungsi sebagai pembawa keberuntungan. Dan tato barong bermakna kebajikan dan kebaikan yang berfungsi sebagai penolak hal-hal buruk. Semua simbol dalam 
bentuk tato memberi fungsi sebagai seni lukis tubuh yang bernilai ekonomi",(Wawancara, 14/09/2019).

Berdasarkan hasil wawancara tersebut di ketahui bahwa simbol suci agama Hindu dalam bentuk tato memiliki fungsi sebagai seni lukis tubuh yang memiliki nilai ekonomi. Menurut Bapak Nengah Merti tato ganesha memiliki makna kebijaksanaan dan kecerdasan yang berfungsi sebagai penolak bala (bahaya). Tato dengan simbol om kara memiliki makna Tuhan Yang Maha Esa dan berfungsi sebagai pemberi keberuntungan dan simbol barong bermakna kebaikan dan berfungsi sebagai penolak hal-hal buruk.

\section{Makna Simbol Suci Agama Hindu Dalam Tato}

Simbol suci agama Hindu memiliki makna yang suci dan sakral. Namun setelah dikomodifikasi makna suci dari simbol agama tersebut berubah maknanya. Makna simbol suci yang telah dikomodifikasi tersebut dapat dilihat pada Tabel 9 sebagai berikut:

Tabel 9. Makna Simbol-Simbol Suci Agama Hindu Dalam Tato

\begin{tabular}{lll}
\hline Jenis & Makna \\
\hline $\begin{array}{l}\text { Manusia } \\
\text { Berkepala }\end{array}$ & $\begin{array}{l}\text { Simbol Ganesha } \\
\text { memiliki makna } \\
\text { kebijaksanaan } \\
\text { (Dewa }\end{array}$ \\
Ganesha) & & $\begin{array}{l}\text { Simbol Om Kara } \\
\text { memiliki Makna } \\
\text { Tuhan Yang } \\
\text { Maha Esa }\end{array}$ \\
\hline Binatang & \\
(Barong )
\end{tabular}

Sumber: Hasil Wawancara, 2019.

Berdasarkan Tabel 9 diatas dapat dijelaskan bahwa makna simbol-simbol suci agama Hindu dalam bentuk tato memiliki makna yang berbeda dengan makna simbol suci sebenarnya. Makna simbol Dewa Ganesha yaitu bermakna sebagai kebijaksanaan dan kecerdasan. Om Kara memiliki makna sebagai pembawa keberuntungan. Dan makna tato barong memiliki makna sebagai penolak bala (hal-hal buruk yang akan terjadi).

\section{SIMPULAN DAN SARAN Simpulan}

Simbol suci agama Hindu merupakan benda yang bernilai sakral dan difungsikan sebagai sarana atau media untuk meningkatkan keyakinan dan ketaqwaan umat beragama terhadap Tuhan Yang Maha Esa. Dalam ajaran agama Hindu, simbol suci di bedakan menjadi 5 bentuk, yaitu: berbentuk manusia dengan segala kelebihannya, berbentuk binatang, berbentuk manusia berkepala binatang, berbetuk manusia berkepala tumbuhan, berbentuk huruf dan benda langit.

Komodfikasi simbol suci agama Hindu dalam bentuk tato merupakan suatu hal yang merubah nilai suci atau nilai sakral dari suatu simbol menjadi simbol yang bernilai komersil dan diperuntunkan untuk memenuhi kebutuhan pasar. Komodifkasi ini terjadi karena belum adanya aturan atau undang-undang yang mengatur tentang penggunaan simbol suci sebagai tato. Dan terjadinya komodifkasi terhadap simbol suci ini karena adanya ketertarikan wisatawan akan kebudayaan serta agama Hindu di Bali.

Bentuk komodifkasi simbol suci agama Hindu ini beragama mulai dari berbentuk sebagai oleh-oleh atau souvernir, berbentuk tato dan lain sebagainya. Dalam tato bentuk dari simbol suci agama Hindu ini mirip dengan aslinya, tetapi ada sedikit tamabahan variasi untuk menambahkan kesan keindahan atau seni pada tato tersebut.

Komodifikasi simbol suci dalam tato terjadi pada tataran bentuk, fungsi dan makna dari simbol suci agama Hindu. Bentuknya tidak berubah dari aslinya namun letak penempatan simbol suci berubah. Seharusnya simbol suci ini diletakan di tempat suci seperti merajan, pura dan lain sebagainya, namun dalam bentuk komodifikai letaknya menjadi di tubuh manusia.

\section{Saran}

Saran bagi pemerintah untuk menanggulangi terjadinya pelecehan terhadap simbol suci agama Hindu, sebaiknya pemerintah membuat aturan tertulis tentang penggunaan simbol-simbol suci agama Hindu 
Jurnal IPTA

p-ISSN: 2338-8633

Vol. 8 No. 1,2020

khususnya aturan tentang penggunaan simbol suci agama dalam bentuk tato.

Saran untuk seniman tato sebaiknya lebih memperhatikan bagaimana nilai dan makna dari simbol suci tersebut serta memperhatikan apa fungsi sebenarnya simbol suci agama Hindu dalam ajaran agama. Sehingga tidak lagi adanya kesalaahan atau pelanggaran dalam penggunaan simbol suci agama Hindu sebagai peluang bisnis khususnya dalam bentuk tato. 


\section{Kepustakaan}

Picard, Michel. 2006. Bali Pariwisata Budaya Dan Budaya Pariwisata. Jakarta : Kepustakaan Populer Gramedia.

Rahma Nadia, Femy. Dan Handayani Retno, Herniawati. 2013. Pengaruh Jumlah Kunjungan Wisatawan, Jumlah Objek Wisata Dan Pendapatan Perkapita Terhadap Penerimaan Sektnor Pariwisata Di Kabupaten Kudus. Jurnal Ekonomi. Vol. 2. No. 2, hlmn 1-9

Setiawan, Ferri Muhammad. 2016. "Commodification of Religious Tradition (Critical Study on Tourismof Islamic Tradition Haul at Pasar Kliwon, Surakarta)" (skripsi). Surakarta. Universitas Sebelas Maret

Titib, I Made. 2001. Teologi \& Simbol-Simbol Dalam Agama Hindu. Surabaya : Badan Litbang Parisada Hindu Dharma Indonesia Pusat.

Widana, I Ketut. 2018. "Tatto Ganesha, Tatu Bagi Umat Hindu" (online), (https://www.unhi.ac.id/id/agamabudaya/detail-agama-budaya/TATTOGANESA,-TATU--BAGI-UMATHINDU, diakses tanggal 26 Agustus 2019. 